\title{
ANALISIS TINGKAT KEUNTUNGAN USAHA RUMAH TANGGA KUE LUMPIA DI KELURAHAN BUMI NYIUR KECAMATAN WANEA
}

\author{
Novel Novri Sumampouw \\ O. Esry Laoh \\ Lyndon R.J. Pangemanan
}

\begin{abstract}
The objective of this research is to to determine the level of profit from the Cake Lumpia households business in the Bumi Nyiur Village Wanea districts. The method used in this study is the case study method. The data used in this study are primary data and secondary data. Primary data were collected in the field directly from the source in this research is the owner of household enterprises cakes spring rolls, for the purpose of research and the data has not been published before. This data was obtained through interviews based on questionnaires that are relevant and have been prepared. As for the secondary data includes village profiles will be obtained from government agencies associated with this research. To determine the amount of benefit artisans will use a rat stamp benefit analysis followed by analysis of $R$ / $C$ to determine the feasibility of this venture. These results indicate that the average total revenue in this business is $R p$. 1,000,000 / day, with a total production cost of Rp. 283,896.7. Then the total profit earned in spring roll pastry business in Bumi Nyiur Village, District of Wanea is Rp. 716,103.3 / day. Analysis of R / C who do show that the average household businesses spring rolls baking in the Village Earth Nyiur District of Wanea experiencing gains, where the $R$ / C ratio of 3.52 and it can be concluded that the business is feasible to run.
\end{abstract}

Key words: The level of profit, Lumpia Cake, Manado

\begin{abstract}
ABSTRAK
Penelitian ini bertujuan untuk mengetahui tingkat keuntungan dari usaha rumah tangga Kue Lumpia di Kelurahan Bumi Nyiur kecamatan Wanea. Metode yang digunakan dalam penelitian ini adalah metode studi kasus. Data yang digunakan dalam penelitian ini adalah data primer dan data sekunder. Data primer diperoleh di lapangan langsung dari sumbernya yang dalam penelitian ini adalah pemilik usaha rumah tangga kue lumpia, guna kepentingan penelitian dan data tersebut belum pernah dipublikasikan sebelumnya. Data ini diperoleh melalui wawancara berdasarkan kuesioner yang relevan dan telah dipersiapkan. Sedangkan untuk data sekunder meliputi profil desa akan diperoleh dari instansi pemerintah yang terkait dengan penelitian ini. Untuk mengetahui besaran keuntungan pengrajin cap tikus akan menggunakan analisis keuntungan yang dilanjutkan dengan analisis $\mathrm{R} / \mathrm{C}$ untuk mengetahui tingkat kelayakan usaha ini. Hasil penelitian ini menunjukan bahwa rata-rata total penerimaan dalam usaha ini adalah Rp. 1.000.000/hari, dengan total biaya produksi sebesar Rp. 283.896,7. Maka total keuntungan yang diperoleh dalam usaha kue lumpia di Kelurahan Bumi Nyiur Kecamatan Wanea adalah sebesar Rp. 716.103,3/hari. Analisis R/C yang dilakukan menunjukan bahwa secara rata-rata usaha rumah tangga pembuatan kue lumpia di Kelurahan Bumi Nyiur Kecamatan Wanea mengalami keuntungan, dimana dengan R/C ratio sebesar 3,52 dan dapat disimpulkan bahwa usaha ini layak untuk dijalankan.
\end{abstract}

Kata kunci: Analisis Tingkat Keuntungan, Kue Lumpia, Manado 


\section{PENDAHULUAN}

\section{Latar Belakang}

Sektor pertanian dan sektor industri merupakan dua sektor yang memegang peranan penting dalam perekonomian Indonesia. Sebagai andalan dalam pembangunan ekonomi, kedua sektor ini diharapkan mampu memberikan sumbangan dalam usaha peningkatan dan pendapatan yang merata bagi masyarakat. Pertanian yang merupakan sektor primer dalam suatu perekonomian, pengembangan dan pembangunanya harus dilakukan secara matang sejalan dengan pengembangan sektor industri dan jasa yang menjadi pendukung sehingga tidak terjadi kepincangan dalam perekonomian. Sektor pertanian yang handal merupakan syarat bagi pengembangan sektor industri dan jasa. Pengembangan usaha di sektor pertanian dan industri perlu didorong dan dibina menjadi suatu usaha yang berkembang, sehingga mampu mandiri dan dapat meningkatkan pendapatan masyarakat.Selain itu juga dengan adanya pengembangan usaha dapat memberikan perluasan lapangan kerja serta mampu meningkatkan perannya dalam menyediakan barang dan berbagai komponen untuk memenuhi keperluan masyarakat dan prmintaan pasar, dalam upaya memperkokoh perekonomian nasional.

Melalui pengembangan industri yang terkait dalam pertanian diharapkan pendapan dan kesejahteraan petani maupun pengusaha industri, khususnya usaha kecil menengah dan rumah tangga dapat meningkat lebih cepat, dan pada akhirnya ketimpang distribusi kesejahteraan ini dapat dikurangi. Alternatif dalam pembangunan sektor industri adalah pembangunan industri kecil yang didalamnya menyangkut industri rumah tangga dan kerajinan rakyat.

Usaha kuliner atau makanan di Kota Manado sedang mengalami perkembangan yang relatif pesat. Perkembangan yang pesat ini menyebabkan semakin banyak orang tertarik untuk menjalankan usaha seperti ini. Meningkatnya jumlah usaha kuliner atau makanan akan meningkatkan tingkat persaingan diantara produsen makanan siap saji, khusunya rumah makan yang menghidangkan produk kuliner yang sejenis. Banyak ahli manajemen pun memprediksi, dengan situasi ekonomi seperti saat ini membuat persaingan usaha kuliner menjadi sulit untuk dihindari, bahkan akan semakin meningkat. Kegiatan usaha kuliner mempunyai tujuan utama untuk mendapatkan keuntungan semaksimal mungkin (Nurahman, 2010). Kegiatan usaha tersebut tidak hanya diam menunggu konsumen, tetapi harus dapat menarik hati konsumen. Dalam usaha mencari konsumen, kegiatan usaha kuliner harus mengetahui apa yang sedang diinginkan dan sesuai dengan selera konsumen, karena dengan begitu kegiatan usaha kuliner akan mampu menjual produk makanan yang ditawarkannya (Andana, 2010).

\section{Deskripsi Usaha Kecil}

Usaha Kecil dan Menengah disingkat UKM adalah sebuah istilah yang mengacu ke jenis usaha kecil yang memiliki kekayaan bersih paling banyak Rp. 200.000.000, yang tidak termasuk tanah_dan bangunan tempat usaha. Menurut Keputusan Presiden RI no. 99 tahun 1998, pengertian usaha kecil adalah kegiatan ekonomi rakyat yang berskala kecil dengan bidang usaha yang secara mayoritas merupakan kegiatan usaha kecil dan perlu dilindungi untuk mencegah dari persaingan usaha yang tidak sehat.

Usaha kecil adalah kegiatan ekonomi rakyat yang berskala kecil, dan memenuhi kekayaan bersih atau hasil penjualan tahunan serta kepemilikan sebagaimana diatur dalam undang-undang (Tohar, 2011). Sedangkan menurut Ina Primiana (2009), mendefinisikan pemgembangan usaha kecil adalah sebagai berikut :

1. Pengembangan empat kegiatan ekonomi utama (core business) yang menjadi motor penggerak pembangunan, yaitu agribisnis, industri manufaktur, sumber daya manusia (SDM), dan bisnis kelautan.

2. Pengembangan kawasan andalan, untuk dapat mempercepat pemulihan perekonomian melalui pendekatan wilayah atau daerah, yaitu dengan pemilihan wilayah atau daerah untuk mewadahi program prioritas dan pengembangan sektorsektor dan potensi.

3. Peningkatan upaya-upaya pemberdayaan masyarakat. 
Sedangkan Financial Accounting Standard Board (FASB) dalam Ahmed Riahi Balkaoui (2005), mendefinisikan perusahaan kecil sebagai sebuah perusahaan yang operasinya relatif kecil, biasanya dengan pendapatan total kurang dari $\$ 5$ juta per bulan. Perusahaan itu umumnya adalah :

1. Dikelola oleh pemilik sendiri

2. Memiliki beberapa pemilik lain, jika ada

3. Semua pemilik secara aktif terlibat dalam menjalankan urusan-urusan perusahaan kecuali mungkin anggota keluarga tertentu

4. Jarang terjadi pemindahan hak kepemilikan

5. Memiliki struktur modal yang sederhana

Kwartono Adi (2007) mendefinisikan usaha kecil adalah sebagai berikut; usaha kecil adalah kegiatan ekonomi rakyat yang memiliki kekayaan bersih paling banyak Rp 200.000.000,- tidak termasuk tanah dan bangunan tempat usaha atau yang memiliki hasil penjualan tahunan paling banyak Rp 1.000.000.000,- dan milik Warga Negara Indonesia. Zulkarnain (2006) mendefinisikan pengertian usaha kecil adalah kegiatan ekonomi rakyat yang memenuhi kriteria sebagai :

1. Usaha yang memiliki kekayaan bersih paling banyak Rp 200.000.000, tidak termasuk tanah dan bangunan tempat usaha.

2. Usaha yang memiliki penjualan tahunan paling banyak Rp 1.000.000.000

3. Usaha yang berdiri sendiri, bukan perusahaan atau cabang perusahaan yang dimiliki, dikuasai,atau terafiliasi, baik langsung maupun tidak langsung dengan usaha menengah atau skala besar.

4. Berbentuk badan usaha yang dimiliki perseorangan, badan usaha yang tidak berbadan hukum, termasuk koperasi.

Dari berbagai definisi diatas, dapat disimpulkan bahwa di dalam usaha kecil ada dua hal yang perlu diperhatikan (Moehar,2011) yaitu:

1. Pemusatan kepemilikan dan pengawasan di tangan seseorang atau beberapa orang

2. Terbatasnya pemisahan dalam perusahaan

Undang-Undang No. 20/2008 tentang Usaha Mikro, Kecil dan Menengah menerangkan bahwa usaha kecil merupakan usaha ekonomi produktif yang berdiri sendiri, yang dilakukan oleh orang perorangan atau badan usaha yang bukan merupakan anak perusahaan atau bukan cabang pe- rusahaan yang dimiliki, dikuasai, atau menjadi bagian baik langsung maupun tidak langsung dari usaha menengah atau usaha besar yang memiliki kekayaan bersih lebih dari Rp. 50.000.000,00 (lima puluh juta rupiah) sampai dengan paling banyak Rp. 500.000.000,00 (lima ratus juta rupiah) tidak termasuk tanah dan bangunan tempat usaha atau memiliki hasil penjualan tahunan lebih dari Rp. 300.000.000,00 (tiga ratus juta rupiah) sampai dengan paling banyak Rp. 2.500.000.000,00 (dua milyar lima ratus juta rupiah). Menurut Badan Pusat Statistik batasan usaha kecil adalah usaha yang memiliki pekerja 5 sampai 19 orang.

\section{Definisi Industri Rumah Tangga Pangan}

Industri rumah tangga (Home industry) merupakan bentuk usaha yang dikelola rumah tangga dengan skala usaha relatif kecil. Menurut Tambunan (2004), salah satu karakteristik home industry adalah struktur permodalan sangat bergantung pada modal pribadi sehingga merupakan kendala yang sangat besar bagi perkembangan usaha. Keterlibatan lembaga keuangan sangat diperlukan dalam perkembangan usahanya. Mekanisme kemitraan antara Industri rumah tangga dengan lembaga keuangan merupakan hal yang perlu dikaji agar sinergi antara industri rumah tangga dengan lembaga keuangan dapat berjalan.

Industri Rumah Tangga Pangan (IRTP) adalah industri yang mengolah pangan yang bertempat di rumah tempat tinggal dengan peralatan manual hingga semi otomatis (Badan Pengawas Obat dan Makanan, 2003). Definisi lain yang menjelaskan tentang industri rumah tangga adalah definisi oleh Badan Pusat Statistik (Badan Pusat Statistik 2005) yang menggolongkan usaha industri pengolahan di Indonesia ke dalam 4 (empat) kategori berdasarkan jumlah pekerja yang dimiliki oleh suatu usaha tanpa memperhatikan besarnya modal yang ditanam ataupun kekuatan mesin yang digunakan. Empat kategori tersebut, antara lain : 
1. Industri kerajinan rumah tangga, yaitu usaha industri pengolahan yang mempunyai pekerja 1-4 orang.

2. Industri kecil, yaitu perusahaan/usaha industri pengolahan yang mempunyai pekerja 5-19 orang.

3. Industri sedang, yaitu perusahaan/usaha industri pengolahan yang mempunyai pekerja 20-99 orang.

4. Industri besar, yaitu perusahaan/usaha industri pengolahan yang mempunyai pekerja 100 orang atau lebih.

Selanjutnya, BPS menggolongkan jenisjenis usaha, seperti industri makanan minuman (golongan pokok 15), indsutri pengolahan tembakau (golongan pokok 16), industri tekstil (golongan pokok 17), indsutri pakaian jadi (golongan pokok 18), dan lain-lain. Dalam hal ini IRTP masuk dalam golongan pokok 15. Definisi IRTP lainnya adalah berdasarkan UU RI No. 9 tahun 1995 tentang usaha kecil dimana dalam UU ini dijelaskan bahwa yang dimaksud usaha kecil adalah kegiatan ekonomi rakyat yang berskala kecil dan memenuhi kriteria kekayaan bersih atau hasil penjualan tahunan serta kepemilikan sebagaimana diatur dalam UU. Sedangkan kriteria usaha kecil adalah sebagai berikut,

1. Memiliki kekayaan bersih paling banyak $\mathrm{Rp}$ 2.000.000,00 (dua juta rupiah), tidak termasuk tanah dan bangunan tempat usaha

2. Memiliki hasil penjualan tahunan paling banyak Rp 1.000.000.000,00 (satu milyar rupiah)

3. Milik Warga Negara Indonesia

4. Berdiri sendiri, bukan merupakan anak perusahaan atau cabang perusahaan yang dimiliki, dikuasai, atau berafiliasi bail langsung maupun tidak langsung dengan usaha menengah atau usaha besar

5. Berbentuk orang perseorangan, badan usaha yang tidak berbadan hukum, atau badan usaha yang berbadan hukum termasuk koperasi.

Jika dilihat dalam definisi usaha kecil seperti pada UU RI No. 9 tahun 1995 tersebut maka IRTP masuk dalam usaha kecil yang bergerak di bidang pangan.

\section{Faktor - Faktor yang Menunjang Pengem- bangan Industri Pengolahan Hasil Pertanian}

\section{Bahan Baku}

Bahan baku merupakan bahan yang membentuk bahan integral dari produk jadi. Bahan baku yang diolah dalam usaha pengolahan hasil pertanian dapat diperoleh dari pengadaan sendiri, pembelian secara lokal, bahkan pembelian secara impor. Adisaputro (2008) mengatakan bahwa jenis-jenis bahan baku dibedakan menjadi 2, yaitu :

a. Bahan baku langsung, yaitu semua bahan yang merupakan bagian dari barang jasa yang dihasilkan. Biaya yang dikeluarkan untuk membeli bahan mentah langsung ini mempunyai hubungan erat yang sebanding dengan jumlah barang jadi yang dihasilkan.

b. Bahan baku tidak langsung, yaitu bahan baku yang ikut berperan dalam proses produksi, tetapi secara tidak langsung tampak pada barang jadi yang dihasilkan.

\section{Modal}

Dalam pengertian ekonomi, modal adalah barang atau uang yang bersama-sama faktor produksi tanah dan tenaga kerja menghasilkan barang baru (Dantes, 2012). Sehubungan dengan kepemilikan modal, pengusaha diklasifikasikan sebagai pengusaha besar, kaya, cukupan, dan komersial, serta pengusaha kecil. Dalam pengembangan usaha, ketersediaan modal dalam jumlah cukup, dan tepat waktu merupakan unsur penting dan strategis. Modal dalam bentuk uang tunai sangat diperlukan bukan hanya untuk membeli sarana produksi. Pelaksanaan kegiatan usaha pasti memerlukan modal sehingga tidak terlepas dari masalah pendanaan dan manajemen keuangan.

\section{Tenaga Kerja}

Tenaga kerja sebagai salah satu faktor produksi dapat berupa tenaga kerja manusia, hewan, atau mesin-mesin. Tenaga kerja manusia terdiri atas tenaga kerja pria, wanita, dan anak-anak. Tenaga kerja dapat mengerjakan semua jenis pekerjaan usahatani berdasarkan tingkat kemampuannya. Akan tetapi, kerja manusia itu dipengaruhi oleh umur, pendidikan, keterampilan, pengalaman, tingkat kecukupan, tingkat kesehatan, dan faktor alam, 
seperti iklim dan kondisi lokasi usaha. Tenaga kerja dalam kegiatan usaha dapat diperoleh dari dalam keluarga, yaitu tenaga kerja yang tidak dibayar upahnya dan tenaga kerja luar keluarga yaitu tenaga kerja yang dibayar upahnya.

Dalam proses produksi sebagai suatu struktur dasar aktivitas perekonomian, tenaga kerja merupakan faktor yang sangat penting, karena tenaga kerja tersebut bertindak sebagai pelaku ekonomi, berbeda dengan faktor produksi lainnya yang bersifat pasif (seperti modal, bahan baku, mesin, dan tanah). Tenaga kerja berkemampuan bertindak aktif, mampu mempengaruhi dan melakukan manajemen terhadap faktor produksi lainnya yang terlibat dalam proses produksi (Sumarsono, 2003)

\section{Manajemen}

Manajemen berasal dari kata to manage yang berarti mengatur, sedangkan secara istilah manajemen dapat diartikan sebagai suatu proses yang terdiri dari tidakan-tindakan perencanaan, pengorganisasian, penggerakan, dan pengendalian yang dilakukan untuk mencapai sasaran-sasaran yang telah ditentukan melalui pemanfaatan sumber daya alam dan sumber daya lainnya yang dikuasai. Terdapat enam unsur pokok manajemen, yaitu manusia, uang, bahan, mesin, pasar dan metode. Pola usaha pengolahan hasil pertanian yang kebanyakan masih bersifat tradisional merupakan sebab dari rendahnya produktifitas. Karena itulah agar dapat memberikan keuntungan yang optimal diperlukan manajemen yang dapat merangkum faktor-faktor alam, tanah, modal, tenaga kerja dan teknologi dengan faktor sarana dan prasarana serta pemasarannya (Rusli, 2010).

Manajemen usaha adalah pengolahan atau ketatalaksanaan pertanian sebaik-baiknya secara terencana, terorganisasi atau terkontrol dalam batasan fungsi produksi yaitu mengatur faktor-faktor alam, tenaga kerja dan modal dengan tujuan mencapai keberhasilan usaha yang akan dikerjakan. Secara umum terdapat empat fungsi manajemen dalam kegiatan usaha (Nitisusastro, 2012), yaitu :

a. Planning (perencanaan), yaitu proses penentuan tujuan dan pedoman pelaksanaan dengan memilih alternatif terbaik dari beberapa alternatif yang sudah ada b. Organizing (pengorganisasian), yaitu suatu proses penentuan, pengelompokan, dan pengaturan berbagai macam aktivitas dalam kegiatan usaha untuk mencapai tujuan utama

c. Actuating (penggerakan), yaitu proses mengarahkan dan mengatur seluruh sumber daya yang dikuasai agar dapat bekerjasama dan bekerja secara efektif untuk mencapai tujuan sesuai dengan ketetapan-ketetapan dalam perencanaan

d. Controlling (pengawasan), yaitu proses mengawasi setiap tahap dalam kegiatan usaha dan mengkoreksi setiap terjadi kesalahan

\section{Teknologi}

Teknologi merupakan suatu teknik yang digunakan untuk semakin menunjang kegiatan produksi dalam suatu industri agar apa yang dihasilkan menjadi semakin maksimal. Dalam artian, teknologi bukan hanya sekedar alat atau benda yang hanya digunakan dalam kegiatan usaha untuk jangka waktu tertentu, melainkan seperangkat ide, teknik maupun upaya atau kegiatan untuk memenuhi kebutuhan masyarakat (Kuriawan, 2005).

Teknologi yang dianggap baru juga tidak perlu harus yang canggih, tetapi yang sangat sederhana pun bisa disebut inovasi teknologi. Dengan adanya adopsi suatu teknologi baru maka kemungkinan akan terjadi perubahan, dan dengan adanya perubahan itu membuka peluang untuk terjadinya perbaikan. Suatu pembaharuan teknologi bisa hanya bersifat perbaikan terhadap cara lama. Perbedaan antara perbaikan dan inovasi hanya pada derajat perubahannya. Perubahan ini merupakan hakikat dari setiap pembangunan, namun tentunya bukan asal perubahan tetapi perubahan yang bersifat perbaikan atau peningkatan, serta perubahan yang mendatangkan sesuatu yang lebih baik dengan menggunakan alat ataupun teknik yang sesuai dengan kegiatan usaha.

\section{Distribusi dan Pemasaran Produk}

Konsep distribusi produk olahan hasil pertanian harus berjalan secara efisien agar keuntungan yang diharapkan dapat terealisasi dengan baik. Ini menandakan bahwa kegiatan distribusi dalam suatu usaha bisnis harus dikoordinasi dan dikelolah dengan cara yang baik. Menurut Kotler dalam buku 
Manajemen Pemasaran (2002), kegiatan distribusi dalam pemasaran adalah suatu proses sosial yang di dalamnya terdapat individu dan kelompok mendapatkan apa yang mereka butuhkan dan inginkan dengan menciptakan, menawarkan, dan secara bebas mempertukarkan produk yang bernilai dengan pihak lain.

Konsep distribusi produk bertujuan untuk memberikan kepuasan terhadap keinginan dan kebutuhan konsumen. Kegiatan usaha agribisnis yang berdasar pada konsep distribusi ini harus diarahkan untuk memenuhi dan memuaskan keinginan konsumen. Secara definitif, dapat dikatakan bahwa konsep distribusi produk dalam pemasaran adalah falsafah bisnis yang menyatakan bahwa pemuasan kebutuhan konsumen merupakan syarat ekonomis dan sosial bagi kelangsungan hidup perusahaan (Swasta, 2006). Dari definisi tersebut, usaha agribisnis memiliki konsekuensi seluruh kegiatan usaha harus diarahkan untuk mengetahui kebutuhan konsumen dan mampu memberikan kepuasan agar mendapat laba dalam jangka panjang. Konsep distribusi produk hasil usaha juga menyatakan bahwa kunci untuk meraih tujuan organisasi adalah menjadi lebih efektif dari pada para pesaing dalam memadukan kegiatan pemasaran guna menetapkan dan memuaskan kebutuhan pasar sasaran (Kotler, 2006). Dewasa ini konsep pemasaran mengalami perkembangan yang semakin maju sejalan dengan majunya masyarakat dan teknologi.

\section{Definisi Kue Lumpia}

Di Indonesia, lumpia dikenal sebagai jajanan khas Semarang dengan tata cara pembuatan dan bahan-bahan yang telah disesuaikan dengan tradisi setempat. Lumpia merupakan hasil perpaduan budaya kuliner Tionghoa dan Jawa. Lumpia dijadikan salah satu Signature Dish kuliner Kota Semarang. Lumpia Semarang memiliki kekhasan tersediri, terlihat dari tampilan ukurannya, dimana lumpia Semarang lebih besar dibandingkan lumpia yang ada di daerah lain, selain itu cita rasa lumpia Kota Semarang juga berbeda dengan lumpia pada umumnya. Wisatawan yang berkunjung ke Kota Semarang, baik domestik maupun mancanegara kurang lengkap jika belum menikmati lumpia Gang Lombok di kawasan pecinan Kota Semarang. Lumpia Gang Lombok diyakini sebagai cikal bakal perkembangan lumpia Semarang. Lumpia Semarang mempunyai sejarah panjang yang sangat menarik untuk dijabarkan dari perspektif sejarah. Lumpia yang lebih dikenal sebagai makanan khas Kota Semarang merupakan makanan bercita rasa etnis Tionghoa dan Jawa yang menjadi identitas etnis Tionghoa peranakan Semarang. Melalui lumpia, etnis Tionghoa Semarang mampu menunjukkan eksistensinya ditengah masyarakat pribumi, bahwa produk budaya etnis Tionghoa peranakan masih diterima walaupun pemerintah memperlakukan etnis Tionghoa peranakan secara deskriminatif (Lamun, 2008).

Lumpia atau terkadang dieja sebagai lun pia adalah sejenis jajanan tradisional Tionghoa. Kata lumpia berasal dari dialek Hokkian dari pelafalan runbing dalam dialek utara dan dalam bahasa Khek atau bahasa Hakka, lumpia disebut pokppya (pokpia).

\section{Gambar 1. Kue lumpia}

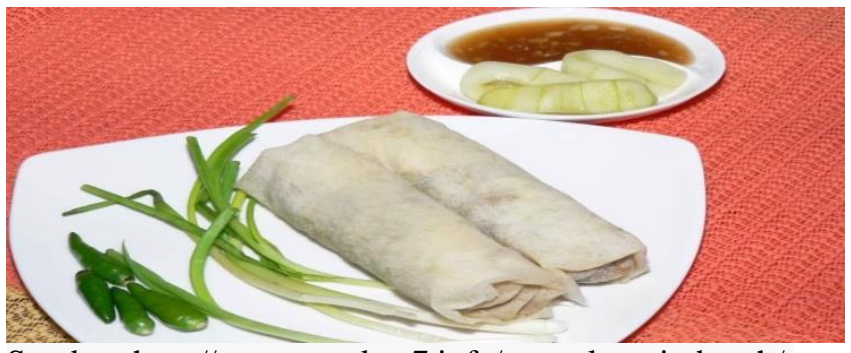

Sumber: http://resepmasakan7.info/resep-lumpia-basah/.

Menurut kamus besar bahasa Indonesia lumpia adalah makanan yang berupa dadar yang berisi daging, rebung, dan sebagainya, lalu di gulung dan digoreng, namun juga ada yang direbus. Lumpia berasal dari kata lun bing, dalam dialek Hokkian berbunyi lun pia yang berarti kue bulat. Lumpia di di Tiongkok disebut dengan chun juan, dimana chun berarti musim semi dan juan berarti menggulung. Secara harafiah dalam bahasa Inggris menjadi spring roll, yang kemudian diakui secara internasional makanan yang digulung dan berbentuk bulat panjang ini disebut dengan spring roll. Lumpia diberi nama berdasarkan bentuk makanannya, yaitu lun artinya gulung (Bahasa Jawa) dan pia artinya kue (bahasa Hokkian). Jadi lumpia atau lunpia adalah kue yang berbentuk gulung. Bagi etnis Tionghoa Semarang, lumpia tidak diwajibkan dalam ibadah tahun baru. Secara umum, lumpia terdiri dari lembaran tipis 
tepung gandum yang dijadikan sebagai pembungkus isian yang umumnya adalah rebung, telur, sayuran segar, daging, atau makanan laut (Lamun, 2008)

Kue lumpia bermula hanya untuk memenuhi hidup satu keluarga percampuran etnis Tionghoa dengan penduduk pribumi, penjualannya pun hanya sebatas di kawasan pecinan yang mayoritas dihuni oleh etnis Tionghoa. Perkembangan lumpia hanya sebatas di lingkungan etnis Tionghoa, setelah peraturan Wijkenstelsel dihapuskan, kawasan pecinan tidak lagi dikhususkan untuk etnis Tionghoa, etnis Tionghoa sudah banyak yang keluar dari pecinan, maka tidak dapat dipungkiri jika lumpia tidak hanya dikenal oleh etnis Tionghoa, namun juga dikenal oleh penduduk Indonesia. Transformasi lumpia dari kuliner rakyat biasa menjadi kuliner yang bersifat universal melalui berbagai tahap (Andana, 2010). Kuliner keluarga, diperkenalkan dan berkembang di lingkungan etnis Tionghoa peranakan di kawasan Pecinan Semarang, kemudian diperkenalkan kepada penduduk Semarang pada awalnya dan dengan cara dipasarkan di pusat wilayah luar Pecinan. Saat ini, kue lumpia dikenal luas oleh berbagai lapisan masyarakat, tak terkecuali para pejabat daerah ataupun pejabat negara. Semakin meluasnya jangkauan lumpia membuat lumpia bertansformasi menjadi kuliner identitas etnis Tionghoa peranakan, khususnya dalam perkembangannya menjadi kuliner khas di beberapa daerah di Indonesia.

\section{Teori Produksi}

Teori produksi adalah studi tentang produksi atau proses ekonomi untuk mengubah faktor produksi (input) menjadi hasil produksi (output). Produksi menggunakan sumber daya untuk menciptakan barang atau jasa yang sesuai untuk digunakan. Dalam teori produksi, produksi adalah suatu kegiatan untuk menambah nilai guna pada suatu barang. Produksi di ukur sebagai "tingkat hasil produksi (output) per periode waktu" karena merupakan konsep aliran ekonomi.

Ada 3 aspek proses produksi yaitu kuantitas barang atau jasa di hasilkan, bentuk barang atau jasa diciptakan, dan distribusi temporal dan spasial dari barang atau jasa yang di hasilkan. Proses produksi dapat didefinisikan sebagai kegiatan yang meningkatkan kesamaan antara pola permintaan barang atau jasa dan kuantitas, bentuk ukuran, panjang dan distribusi barang atau jasa tersedia bagi pasar.

Fungsi produksi adalah suatu persamaan yang menunjukan hubungan ketergantungan antara tingkat input yang digunakan dalam proses produksi dengan tingkat output yang di hasilkan. faktor-faktor produksi dikenal pula dengan istilah input dan jumlah produksi selalu juga disebut sebagai output (Sumarsono, 2003). Fungsi produksi secara matematis sebagai berikut :

$$
\mathbf{Q}=\mathbf{F}(\mathbf{K}, \mathbf{L}, \mathbf{R}, \mathbf{T})
$$

Keterangan :

$$
\begin{aligned}
& \mathrm{Q}=\text { Jumlah output (hasil) } \\
& \mathrm{K}=\text { Kapital (Modal) } \\
& \mathrm{L}=\text { Labour (Tenaga Kerja) } \\
& \mathrm{R}=\text { Raw Material (Kekayaan) } \\
& \mathrm{T}=\text { Teknologi }
\end{aligned}
$$

Menurut Tambunan (2014), dalam teori input sumber daya yang digunakan dalam proses produksi disebut faktor-faktor produksi sebagai berikut :

a) Manusia (Tenaga Kerja)

b) Modal

c) Sumber Daya Alam (Tanah)

d) Skill (Teknologi)

\section{Fungsi Biaya}

Biaya merupakan seluruh sumber daya yang digunakan untuk menghasilkan dan memperoleh suatu barang atau jasa. Biaya dapat diklasifikasikan ke dalam biaya internal dan biaya eksternal. Biaya internal adalah biaya yang dikeluarkan dalam kegiatan proses produksi suatu barang atau jasa. Sedangkan biaya eksternal adalah biaya yang ditanggung oleh masyarakat secara tidak langsung akibat kegiatan proses produksi suatu kegiatan usaha (Wilson, 2007).

Dalam jangka pendek, biaya produksi dapat diklasifikasikan ke dalam biaya tetap (fixed cost atau $F C$ ), biaya variabel (variable cost atau $V C$ ) dan biaya total (total cost/TC). Fixed cost adalah seluruh biaya yang dikeluarkan untuk memperoleh faktor-faktor produksi yang sifatnya tetap. Variabel cost adalah biaya yang dikeluarkan untuk kegiatan produksi berubah-ubah sesuai perubahan jumlah barang atau jasa 
yang dihasilkan. Total cost adalah keseluruhan biaya yang dikeluarkan untuk kegiatan proses produksi. Persamaan yang digunakan adalah sebagai berikut :

Dimana: $\mathrm{TC}=$ Biaya Total

$$
\mathbf{T C}=\mathbf{F C}+\mathbf{V C}
$$

$\mathrm{FC}=$ Biaya Tetap

$\mathrm{VC}=$ Biaya Variabel

Perhitungan biaya tersebut merupakan awal dalam merencanakan keuntungan usaha rumah makan. Besarnya keuntungan ini digunakan untuk menentukan alokasi biaya operasi (operating cost), biaya karyawan (labor cost) dan biaya langsung bahan makanan (food cost).

\section{Konsep Penerimaan}

Total peneriman adalah jumlah produksi dikalikan dengan harga jual yang berlaku (Wilson, 2007). Menurut Kotler (2006), total penerimaan merupakan jumlah uang yang diterima pengusaha rumah makan sebelum dipotong total biaya atau biasa disebut pendapatan kotor setiap bulan dan dinyatakan dalam rupiah $(\mathrm{Rp})$, serta dapat ditentukan dengan menggunakan rumus berikut :

Dimana :

$$
\mathbf{T R}=\mathbf{Q} \times \mathbf{P}
$$

$\mathrm{TR}=$ Total revenue/total penerimaan $(\mathrm{Rp} / \mathrm{bulan}$

$\mathrm{Q}=$ Quantity/jumlah porsi makanan dan minuman yang terjual tiap bulan

$\mathrm{P} \quad=$ Price/harga makanan dan minuman yang terjual $(\mathrm{Rp})$

\section{Konsep Keuntungan Usaha Kuliner}

Keuntungan merupakan hasil berupa uang atau hasil materi lainnya yang dicapai oleh penggunaan kekayaan atau jasa-jasa manusia lewat suatu kegiatan usaha. Keuntungan usaha kuliner sangat dipengaruhi oleh jumlah produk makanan atau minuman yang terjual dalam satu kurun waktu, sehingga kualitas produk dan kestabilan harga jual harus menjadi prioritas yang dilakukan manajemen rumah makan. Menurut Wilson (2007), keuntungan usaha adalah selisih antara penerimaan dan semua biaya dan dapat dirumuskan dalam model persamaan berikut :
Dimana :
$\begin{array}{ll}\mathrm{I} & =\text { Income (Keuntungan Usaha) } \\ \mathrm{TR} & =\text { Total Revenue }(\text { Total Penerimaan) } \\ \mathrm{TC} & =\text { Total Cost } \text { (Total Biaya) }\end{array}$

$$
\mathbf{I}=\mathbf{T R}-\mathbf{T C}
$$

Total penerimaan merupakan sejumlah produk yang terjual dan dikalikan dengan harga masing-masing produk, dan kemudian diakumulasikan. Sedangkan total biaya merupakan akumulasi dari biaya variabel dan biaya tetap. Keuntungan usaha rumah makan selalu menjadi pusat perhatian pemilik (owner) di dalam mengelola usahanya, karena pendapatan usaha mempunyai fungsi untuk memenuhi keperluan sehari-hari dan memberikan kepuasan kepada pengusaha supaya dapat menjalankan dan melanjutkan kegiatan usahanya. Fungsi keuntungan usaha adalah untuk memenuhi kebutuhan keperluan sehari-hari dan memberikan kepuasan agar dapat melanjutkan kegiatannya (Wilson, 2007).

Keuntungan usaha tersebut juga akan digunakan untuk mencapai keinginan dan memenuhi kewajiban-kewajiban dalam kehidupan pengusaha. Dengan demikian besaran keuntungan yang diterima pengusaha rumah makan akan dialokasikan pada berbagai kebutuhan. Keuntungan yang diterima oleh masing-masing kegiatan usaha kuliner dapat berbeda-beda, sekalipun menu makanan dan minuman yang ditawarkan sama.

\section{Konsep Analisis Return Cost of Ratio}

Untuk mengetahui apakah usaha rumah tangga Kue Lumpia "Kios Nia" di Kelurahan Bumi Nyiur Kecamatan Wanea layak dijalankan atau tidak, maka dapat ditentukan dengan melakukan analisis Return Cost of Ratio (Return $\mathrm{R} / \mathrm{C}$ ), yaitu perbandingan antara penerimaan dengan total biaya produksi. Analisis ini menggunakan model persamaan sebagai berikut :

$$
\begin{aligned}
& \mathrm{A}=\mathrm{TR} / \mathrm{TC} \\
& \mathrm{TR}=\mathrm{P} \cdot \mathrm{Q} \\
& \mathrm{TC}=\mathrm{FC}+\mathrm{VC}
\end{aligned}
$$




$$
\mathrm{A}=\{(\mathrm{P} \cdot \mathrm{Q}) /(\mathrm{FC}+\mathrm{VC})\}
$$

Dimana :

$\mathrm{A}=\quad$ Indeks kelayakan keuntungan

$\mathrm{TR} / \mathrm{TC}=$ Rasio perbandingan antara total penerimaan dan total biaya produksi

TR = Total Penerimaan

TC $=$ Total Biaya Produksi

$\mathrm{P} \quad=$ Harga Jual Produk

$\mathrm{Q} \quad=$ Quantity (Total produksi)

$\mathrm{FC} \quad=$ Fixed Cost (Biaya tetap)

$\mathrm{VC}=$ Variable Cost (Biaya variabel)

Dengan kriteria, apabila :

a) Bila $\mathrm{R} / \mathrm{C}=1$, usaha rumah tangga tersebut tidak untung dan tidak rugi

b) Bila $\mathrm{R} / \mathrm{C}<1$, usaha rumah tangga tersebut rugi dan tidak layak dijalankan

c) Bila $\mathrm{R} / \mathrm{C}>1$ usaha rumah tangga tersebut untung dan layak dijalankan

\section{Perumusan Masalah}

Berdasarkan uraian sebelumnya, maka yang menjadi permasalahan dalam penelitian ini adalah berapakah tingkat keuntungan dari usaha rumah tangga Kue Lumpia di Kelurahan Bumi Nyiur Kecamatan Wanea.

\section{Tujuan dan Manfaat Penelitian}

Berdasarkan pada rumusan masalah tersebut, maka tujuan penelitian ini adalah untuk mengetahui tingkat keuntungan dari usaha rumah tangga Kue Lumpia di Kelurahan Bumi Nyiur Kecamatan Wanea.

Manfaat dari penelitian ini adalah diharapkan dapat memberikan informasi secara lebih luas mengenai pengembangan usaha rumah tangga kue lumpia di Kelurahan Bumi Nyiur Kecamatan Wanea sehingga mampu melakukan pengembangan usaha, serta menjadi bahan masukan dan informasi mengenai profil dan potensi usaha tersebut bagi masyarakat luas.

\section{METODOLOGI PENELITIAN}

Tempat dan Waktu Penelitian

Penelitian ini dilaksanakan di Kelurahan Bumi Nyiur Kecamatan Wanea Kota Manado. Penelitian ini dilakukan mulai bulan September sampai Bulan Desember 2015 mulai dari persiapan proposal sampai penyusunan laporan penelitian.

\section{Teknik Pengumpulan Data}

Data yang akan dipakai dalam penelitian ini adalah data primer dan data sekunder. Data primer merupakan data mentah yang diambil oleh peneliti (bukan oleh orang lain) diperoleh di lapangan langsung dari sumbernya yang dalam penelitian ini adalah pemilik usaha rumah tangga kue lumpia, guna kepentingan penelitian dan data tersebut belum pernah dipublikasikan sebelumnya. Data ini diperoleh melalui wawancara berdasarkan kuesioner yang relevan dan telah dipersiapkan.

Teknik wawancara dilakukan melalui tatap muka dan tanya jawab langsung antara pengumpul data dan narasumber atau sumber data. Sedangkan data sekunder diperoleh dari studi kepustakaan berupa literatur, sumber tertulis atau dokumen yang memiliki relevansi dengan penelitian ini. Teknik pengumpulan data yang digunakan dalam penelitian ini adalah sebagai berikut :

a) Observasi, yaitu teknik yang menuntut adanya pengamatan dari peneliti baik secara langsung maupun tidak langsung terhadap objek penelitiannya (Padmowiharjo, 2004). Observasi yang digunakan dalam penelitian ini adalah observasi tidak terstruktur, yaitu observasi yang dilakukan dengan tidak menggunakan pedoman pengamatan. Dalam penelitian ini, penulis melakukan penelitian secara langsung untuk melihat dan mengamati situasi dan kondisi usaha rumah tangga kue lumpia di Kelurahan Bumi Nyiur.

b) Wawancara, yaitu teknik pengumpulan data dengan melakukan dialog langsung antara peneliti dengan responden. Sebelum melakukan wawancara, peneliti telah menyiapkan kuesioner (daftar pertanyaan) yang akan diberikan kepada responden. Responden dalam 
penelitian ini adalah pemilik usah kue lumpia "Kios Nia" di Kelurahan Bumi Nyiur Kecamatan Wanea.

c) Studi kepustakaan, yaitu pengumpulan data dan bahan penelitian yang diperoleh dari buku, jurnal, internet dan sumber lainnya yang berkaitan dengan masalah yang dibahas dalam penelitian ini.

\section{Konsep Pengukuran Variabel}

Variabel yang akan diukur dalam penelitian ini adalah :

1. Profil usaha rumah tangga kue lumpia

2. Produksi (jumlah produksi Kueh Lumpia)

3. Harga jual Kue Lumpia (Rp)

4. Biaya produksi yang dikeluarkan pengusaha untuk menyediakan menu kue lumpia yang ditawarkan, meliputi:

a) Biaya tetap (Rp/hari) yang terdiri:

- Pajak usaha, yaitu retribusi pengusaha rumah makan bagi penerimaan Negara yang dibayarkan kepada pemerintah secara rutin.

- Biaya Penyusutan alat, yaitu komponen biaya yang secara tidak langsung dikeluarkan pengusaha untuk setiap tahun produksi, dalam hal ini pemakaian peralatan pendukung kegiatan usaha. Biaya penyusutan alat dihitung dengan formulasi :

\section{Biaya Penyusutan Alat}

$$
=\frac{\text { Harga Pembelian }- \text { Harga Sisa }}{\text { Umur Ekonomis }}
$$

b) Biaya variabel (Rp/hari), meliputi :

- Bahan baku pembuatan kue lumpia, terdiri dari bahan kulit adonan lumpia, bahan isian lumpia, dan campuran bumbu dapur.

- Upah tenaga kerja setiap 1 kali produksi

- Biaya Transportasi, yaitu biaya distribusi bahan baku dari pasar ke lokasi usaha, serta distribusi produk dari lokasi pembuatan ke lokasi penjualan.

5. Penerimaan, yaitu jumlah uang yang diterima pengusaha rumah makan sebelum dipotong total biaya atau biasa disebut pendapatan kotor setiap hari dan dinyatakan dalam rupiah (Rp), serta dapat ditentukan dengan menggunakan rumus berikut :

\section{$\mathbf{T R}=\mathbf{Q} \times \mathbf{P}$}

Dimana :

$\mathrm{TR}=$ Total revenue/total penerimaan $(\mathrm{Rp} / \mathrm{hari}$

$\mathrm{Q}=$ Quantity/jumlah produk kue lumpia yang terjual tiap hari

$\mathrm{P} \quad=$ Price/harga kue lumpia yang terjual (Rp)

6. Keuntungan usaha, yaitu sejumlah uang yang diperoleh pengusaha kue lumpia yang diperoleh sebagai laba kegiatan usaha kuliner setiap 1 kali produksi (Rp), dimana jumlah keuntungan diperoleh dari hasil penjualan dikurangi dengan biaya yang dikeluarkan

\section{Analisis Data}

Untuk mendeskripsikan profil usaha kue lumpia di Kelurahan Bumi Nyiur Kecamatan Wanea, maka analisis data dilakukan dengan menggunakan metode analisis deskriptif dan akan disajikan dalam bentuk tabel. Sedangkan untuk mengetahui tingkat keuntungan usaha kue lumpia akan menggunakan analisis keuntungan usaha dengan formulasi :

$$
\pi=\mathbf{T R}-\mathbf{T C}
$$

Dimana :

$\pi \quad=$ Income/Keuntungan usaha kue lumpia (Rp)

$\mathrm{TR}=$ Total Revenue $/$ Total penerimaan $(\mathrm{Rp})$

$\mathrm{TC}=$ Total Cost/Total biaya produksi (Rp)

Analisis keuntungan usaha kemudian dilanjutkan dengan analisis Return of Cost Ratio 
yang merupakan perbandingan antara penerimaan dengan total biaya produksi untuk menganalisis kelayakan usaha merupakan (Wilson, 2007). Analisis ini menggunakan model persamaan sebagai berikut :

Dimana :

$$
\mathrm{R} / \mathrm{C}=\mathrm{TR} / \mathrm{T} \mathrm{C}
$$

$\mathrm{R} / \mathrm{C}=$ Indeks Kelayakan Usaha

$\mathrm{TR}=$ Total Penerimaan

$\mathrm{TC}=$ Total Biaya Produksi

\section{HASIL DAN PEMBAHASAN}

\section{Profil Usaha Kue Lumpia "Kios Nia"}

Usaha lumpia Kios Nia mulai berdiri sejak tahun 1993 atau telah berdiri selama 22 tahun dengan pemilik bernama ibu Anece Budiman. Kios lumpia ini terletak di Kelurahan Bumi Nyiur Kecamatan Wanea Kota Manado Provinsi Sulawesi Utara. Kios tempat usaha ini menyediakan kue lumpia basah sebagai hidangan utama yang dijual. Selain kue lumpia, kios ini juga menyajikan beberapa kue tradisional lainnya sebagai menu tambahan, tetapi kurang memberikan kontribusi bagi penghasilan usaha Kios Nia. Pada awalnya, pemilik usaha ini bekerja sebagai juru masak lumpia di salah satu usaha kue tradisional lain di Kota Manado, sehingga memberikan pengalaman dan keahlian bagi pemilik hingga akhirnya mulai merintis usaha ini di Tahun 1993.

Operasional usaha ini berjalan selama 6 hari seminggu (kecuali hari minggu) dengan jam operasional selama 8 jam per hari. Pada malam hari, sejak jam 06.00 sampai 10:00 malam, dilakukan proses pembuatan kulit lumpia dan pengirisan sayur, serta pencampuran bumbu untuk isian lumpia. Kemudian di pagi hari, antara jam 06.00 sampai 09.00 pagi dilakukan pengisian isi lumpia yang telah dilakukan malam sebelumnya serta pelipatan kulit. Agar isian lumpia bertahan lama maka pemilik menyimpan di kulkas.
Usaha ini dijalankan oleh 2 orang tenaga kerja, yaitu Bapak Anace sebagai pemilik dan saudara dari pemilik usaha tersebut.Tenaga kerja tersebut diupah sebesar Rp. 400.000 per minggu. Dalam menjalankan usaha ini, produksi yang dilakukan setiap harinya adalah sebanyak 250 pcs yang didistribusikan ke 3 toko, yaitu Golden pasar swalayan, Cella Bakery dan Restoran Dua Rasa. Sebanyak 100 pcs didistribusikan ke golden, 120 pcs ke Cella Bakery dan 30 pcs ke Restoran Dua Rasa dengan harga Rp. 4.000 per pcs. Sehingga total omzet (penerimaan kotor) untuk penjualan kue lumpia Kios Nia adalah sebesar Rp. 1.000.000 per hari, dengan asumsi tingkat produksi bertahan sebanyak 250 pcs.

Hasil penelitian ini menunjukan bahwa seluruh hasil produksi kue lumpia dijual oleh pengusaha langsung kepada mitra kerja yang selanjutnya menjual produk tersebut secara eceran. Pemilik tidak menjualnya langsung kepada konsumen secara eceran. Untuk saluran pemasaran usaha Lumpia Kios Nia dilakukan pendistribusian ke 3 toko, yaitu Golden Pasar Swalayan, Cella Bakery dan Restoran Dua Rasa. Untuk pemasaran di Golden Pasar Swalayan dan Cella Bakery diantarkan langsung oleh pekerja dengan menggunakan kendaraan sepeda motor milik pribadi, sedangkan Restoran Dua Rasa menggunakan sistem jemput di Kios.

Maka, secara umum ada 2 saluran pemasaran yang dijalankan oleh usaha kue lumpia "Kios Nia” yang ditunjukan pada Gambar 2.:

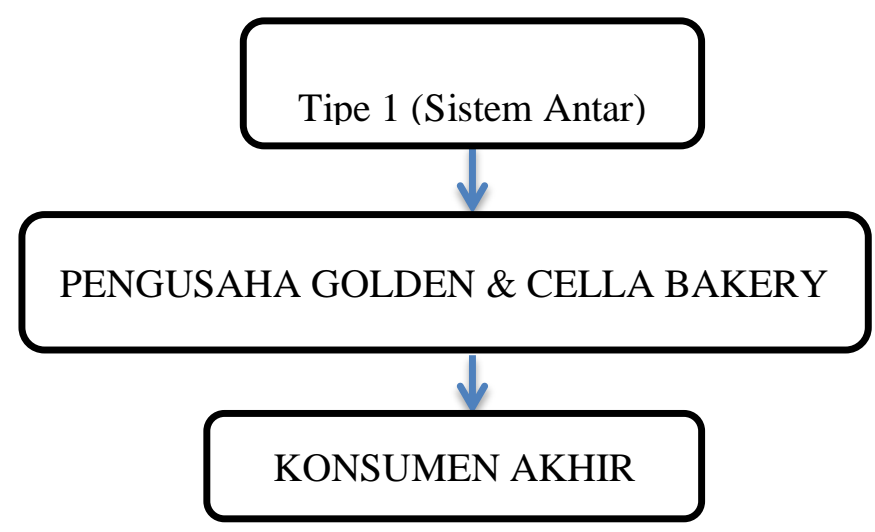

Gambar 2. Saluran Pemasaran Kue Lumpia "Kios Nia" 
Pada saluran pemasaran tipe pertama, pengusaha kue lumpia menyalurkan produknya kepada pedagang pengecer (dalam ha ini Golden Swalayan dan Cella Bakery) yang kemudian dijual kembali kepada konsumen akhir.

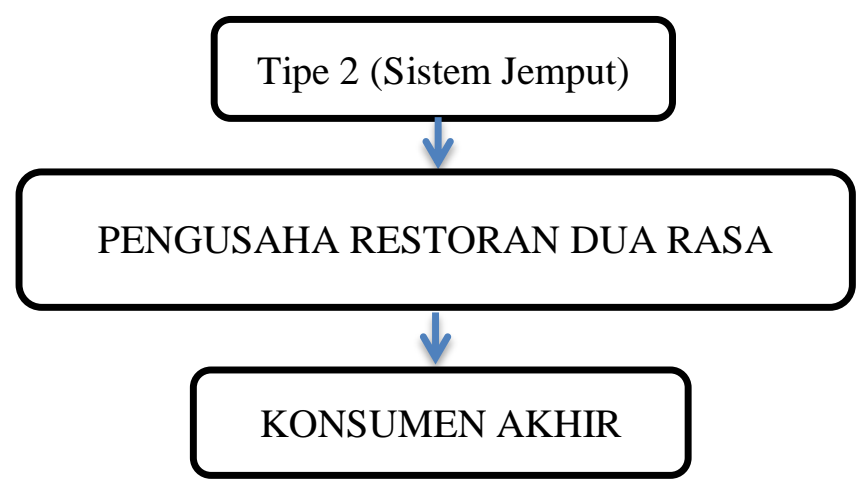

Gambar 3. Saluran Pemasaran Kue Lumpia "Kios Nia"

Sedangkan pada tipe 2, pihak pedagang pengecer, dalam hal ini Restoran Dua Rasa, menjemput langsung kue lumpia dari lokasi produksi. Saluran pemasaran tipe 2 dirasakan lebih menguntungkan bagi pengusaha dikarenakan tidak perlu mengeluarkan biaya untuk distribusi produk, terlebih harga pokok yang dijual kepada pengecer tidak ada perbesaan yakitu tetap Rp. 4.000. Tetap Restoran Dua Rasa biasanya hanya mengambil produk kue lumpia dalam volume yang sedikit, yaitu sebanyak 30 pcs.

Usaha ini dianggap sebagai kegiatan ekonomi yang berkesinambungan dan secara kuantitas mampu menjamin pemenuhan kebutuhan hidup bagi pemilik beserta keluarganya. Pemilik telah mengetahui dan menguasai teknis usaha pembuatan lue lumpia semenjak lama sehingga pemilik memilih untuk memanfaatkan keahlian yang dimiliki untuk meneruskan usaha yang sudah ada. Hasil keuntungan dari usaha pembuatan kue lumpia diakui oleh pemilik dapat mencukupi kebutuhan rumah tangga keluarga, yaitu untuk memenuhi kebutuhan pangan (konsumsi harian), memenuhi keperluan sekolah anak, bahkan keluarga memiliki tabungan dan investasi lainnya, seperti saving di bank maupun dalam bentuk arisan keluarga, serta simpanan untuk keperluan tidak terduga.

Ada beberapa hambatan yang dilalui selama menjalankan usaha ini. Antara lain pada musim tertentu terjadi kelangkaan untuk bahan utama isian lumpia sepeti wortel dan buncis, serta kenaikan harga bahan baku yang mendadak sebagai dampak dari cuaca buruk dan permainan harga bahan baku di pasar. Faktor kesehatan tenaga kerja juga sempat menghambat resistensi bisnis ini.

\section{Tahapan Pembuatan Kue Lumpia Kios Nia}

Varian rasa dari kue lumpia yang dipasarkan hanya jenis lumpia basah dengan tambahan sambal instant (sambal botol) sebagai pelengkap. Berikut bahan dasar dan bumbu yang digunakan dalam memproduksi Kue Lumpia di Kios Nia :

1. Tepung Terigu (bahan utama Kulit Lumpia)

2. Wortel

3. Kembang kol

4. Buncis (kacang panjang)

5. Tauge

6. Kacang Tanah

7. Telur

8. Garam

9. Bawang putih

10. Daun Bawang

11. Daun Seledri

12. Penyedap Masakan

13. Sambal Botol

Sedangkan, dalam pembuatan kue lumpia khas Kios Nia menggunakan alat dan bahan sebagai berikut :

1. Pisau

2. Papan Talenan

3. Parutan sayur

4. Wajan khusus lumpia

5. Kompor gas

6. Loyang plastik

7. Wadah plastik untuk distribusi produk

Proses pembuatan kue lumpia Kios Nia terbagi atas 3 tahapan, yaitu: 1) Tahap pembuatan kulit lumpia, 2) Tahap pembuatan isi lumpia dan 3) proses akhir berupa pembungkusan isi lumpia 
hingga siap didistribusikan. Berikut bagan tahap pembuatan kulit lumpia (Gambar 4).

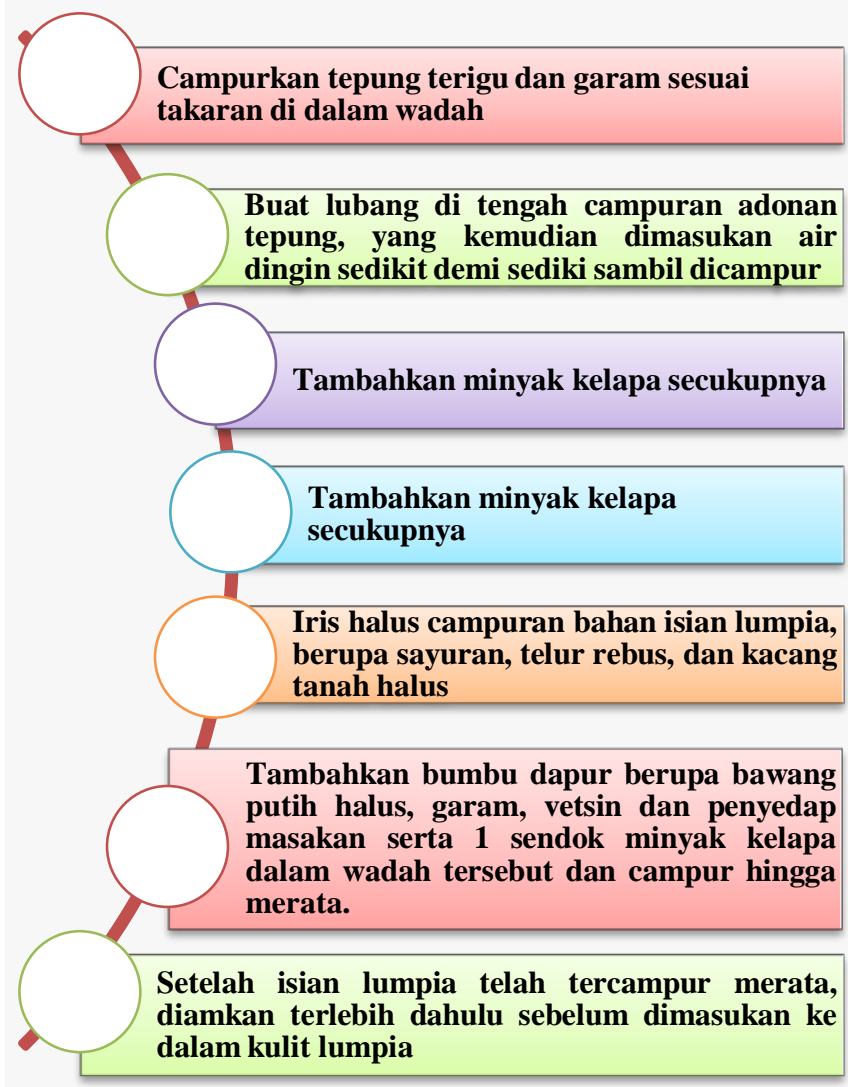

Gambar 4. Bagan pembuatan kulit kue lumpia

Cara membuat kulit lumpia adalah sebagai berikut. Campurkan terigu dan garam di dalam baskom dan diaduk rata.Buat lubang tepat di tengahtengah campuran terigu dan garam, kemudian masukkan telur kedalam lubang. Aduk-aduk hingga rata, dimulai dari tengah menuju ke arah tepi secara perlahan sambil dituangi dengan air sedikit demi sedikit.Tambahkan minyak goreng, kemudian aduk rata. Adonan tersebut dipanaskan di wajan bulat yang dibuat khusus untuk pemilik dengan diameter antara $17 \mathrm{~cm}$ dengan kompor. Setelah wajan hangat, tuangkan satu sendok sayur adonan kulit lumpia secara merata. Masak di atas api kompor sedang sampai kulit lumpia bisa dilepas. Setelah itu kulit lumpia segera diangkat dan didinginkan. Berikut bagan tahap pembuatan isi kue lumpia (Gambar 5).

\begin{tabular}{|c|c|}
\hline 1 & $\begin{array}{l}\text {-Siapkan wadah tempat pembuatan kulit } \\
\text { lumpia }\end{array}$ \\
\hline 2 & $\begin{array}{l}\text { - Campurkan tepung terigu dan garam sesuai } \\
\text { takaran di dalam wadah }\end{array}$ \\
\hline 3 & $\begin{array}{l}\text { - Buat lubang di tengah campuran adonan } \\
\text { tepung, yang kemudian dimasukan air } \\
\text { dingin sedikit demi sediki sambil dicampur }\end{array}$ \\
\hline 4 & - Tambahkan minyak kelapa secukupnya \\
\hline 5 & $\begin{array}{l}\text { - Tuang adonan sebanyak } 1 \text { sendok makan ke } \\
\text { atas wajan khusus pembuat kulit lumpia, } \\
\text { masak hingga kulit lumpia mudah dilepas }\end{array}$ \\
\hline
\end{tabular}

Gambar 5. Bagan pembuatan isian kue lumpia

Sedangkan untuk pembuatan isian kulit lumpia, cukup campurkan isian lumpia berupa potongan kecil dari wortel, kembang kol, buncis (kacang panjang), tauge, kacang tanah halus, irisan telur rebus, garam, bawang putih halus, serta irisan tipis daun bawang dan daun seledri. Setelah proses pembuatah isian lumpia selesai, dilanjutkan dengan proses akhir, yang dapat dijelaskan pada bagan berikut (Gambar 6).

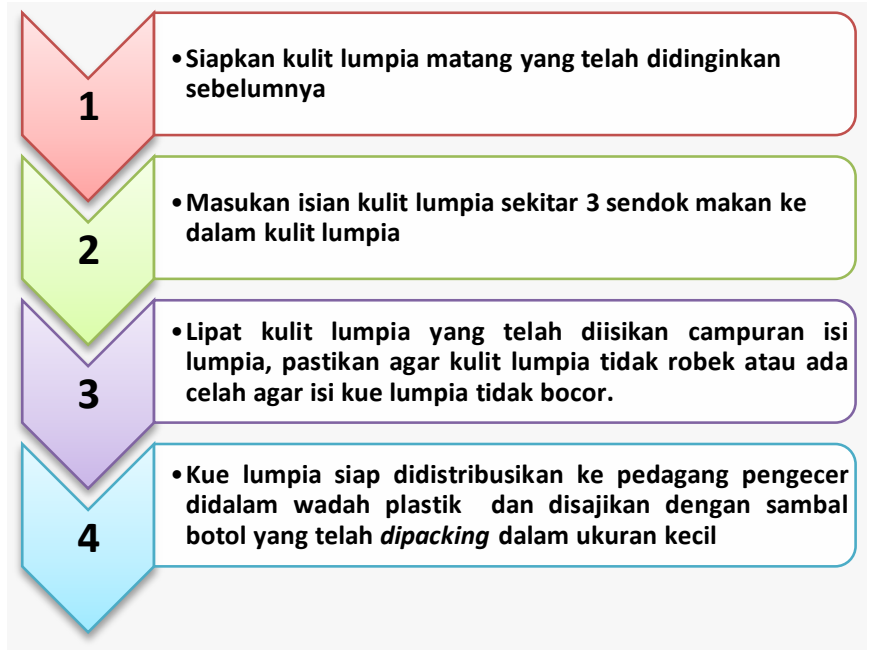

Gambar 6. Bagan proses akhir produksi kue lumpia 
Tahap akhir berupa pengisian lumpia dan pelipatan kulit lumpia. Masukan isian kulit lumpia sekitar 3 sendok makan ke dalam kulit lumpia ke dalam kulit lumpia yang telah dimasak sebelumya. Kemudian Lipat kulit lumpia yang telah diisikan campuran isi lumpia, pastikan aga kulit lumpia tidak robek atau ada celah agar isi kue lumpia tidak bocor. Masukan kue lumpia siap jual ke dalam wadah plastik, serta siapkan sambal botol yang telah dikemas dalam ukuran kecil sebagai bahan pelengkap, kemudian kue lumpia siap didistribusikan ke pedagang pengecer.

\section{Biaya Produksi Kue Lumpia}

Biaya adalah pengeluaran dalam produksi yang tidak dapat dihindarkan. Biaya mempunyai peran yang sangat penting dalam pengambilan keputusan setiap usaha. Besarnya biaya yang dikeluarkan untuk memproduksi akan sangat berpengaruh keuntungan yang akan diperoleh dalam suatu bisnis.

Biaya produksi adalah semua biaya yang dikeluarkan dalam pengolahan kue lumpia dalam satu kali produksi. Komponen biaya dibagi atas biaya tetap dan biaya variabel. Biaya tetap yang difokuskan dalam penelitian ini adalah biaya penyusutan peralatan yang digunakan dan besaran pajak usaha yang dibayarkan pemilik kepada pemerintah setiap tahunnya.

\section{Biaya Tetap}

Biaya tetap adalah biaya yang tidak tergantung dari besar kecilnya volume produksi. Dalam artian, Biaya tetap menjadi jenis biaya yang bersifat statis (tidak berubah) dalam ukuran tertentu. Biaya ini akan tetap kita keluarkan meskipun kita tidak melakukan aktivitas apapun atau bahkan ketika kita melakukan aktivitas yang sangat banyak sekalipun. Dalam proses produksi, biaya tetap akan selalu kita bayarkan atau keluarakan tanpa menghitung berapa banyak produksi yang kita lakukan, baik ketika tidak produksi atau sebalinya saat produksi dilakukan dalam kapasitas maksimal. Jadi dengan kata lain, secara total biaya ini akan selalu sama, tidak terpengaruh oleh jumlah unit yang diproduksi atau jumlah aktivitas yang dilakukan. Semakin banyak unit yang kita produksi atau semakin banyak aktivitas yang dilakukan maka biaya tetap per unit atau peraktivitas yang kita lakukan semakin kecil jumlahnya. Dalam penelitian ini, biaya tetap terdiri atas biaya penyusutan alat dan pajak usaha.

Biaya penyusutan alat merupakan biaya pengurangan nilai yang disebabkan oleh pemakaian alat selama proses berlangsung. Penyusutan yang dihitung adalah umur teknis alat berdasarkan pemakaian alat-alat produksi milik sendiri. Biaya penyusutan alat dapat dilihat pada Tabel 1 berikut.

Tabel 1. Rata-Rata Biaya Penyusutan Alat Produksi Pembuatan Kue Lumpia

\begin{tabular}{lcccc}
\hline \multicolumn{1}{c}{$\begin{array}{c}\text { Alat yang Digunakan dalam } \\
\text { Produksi }\end{array}$} & $\begin{array}{c}\text { Harga beli } \\
\text { alat }(\mathbf{R p})\end{array}$ & $\begin{array}{c}\text { Nilai Sisa } \\
(\mathbf{R p})\end{array}$ & $\begin{array}{c}\text { Umur } \\
\text { ekonomis } \\
(\text { Hari) }\end{array}$ & Biaya Penyusutan (Rp) \\
\hline Pisau & 20.000 & 0 & 1.095 & 18,3 \\
Papan Talenan & 35.000 & 0 & 1.825 & 19,2 \\
Parutan sayur & 35.000 & 0 & 1.825 & 19,2 \\
Wajan khusus lumpia & 60.000 & 0 & 1.825 & 32,9 \\
Kompor gas & 250.000 & 0 & 3.650 & 68,5 \\
Loyang plastik & 75.000 & 0 & 1.825 & 41,1 \\
Tupperware & 125.000 & 0 & 3.650 & $34 ., 2$ \\
\hline \multicolumn{1}{c}{ Total Penyusutan } & & & & $\mathbf{2 3 3 , 3}$ \\
\hline
\end{tabular}

Sumber : Data Primer, 2015 
Tabel 1 menunjukkan bahwa rata-rata penyusutan peralatan dalam produksi pembuatan kue lumpia adalah sebesar Rp. 233,4 per hari atau dalam satu kali produksi dengan menghasikan sebanyak 250 pcs kue lumpia. Dalam biaya tetap usaha ini juga dihitung pajak usaha yang dibayarkan pemilik kepada pemerintah sebesar Rp. 800.000 per tahun, atau sebesar Rp. 2191,7 per hari. Maka total biaya tetap yang dikeluarkan pemilik usaha setiap harinya adalah sebesar Rp. 2425,1 baik jika dilakukan proses produksi maupun tidak menjalankan proses produksi.

\section{Biaya Variabel}

Biaya variabel adalah biaya yang besar kecilnya tergantung dari sedikit atau banyaknya produk dan jasa yang akan dihasilkan. Semakin besar produk yang ingin dihasilkan, biaya tidak tetap akan semakin tinggi, begitu juga sebaliknya. Dalam artian, semakin banyak produk yang ingin dihasilkan, maka material yang dibutuhkan juga akan semakin banyak dan biaya produksinya otomatis ikut menjadi besar. Biaya variabel yang dihitung dalam penelitian ini adalah biaya bahan baku, biaya transportasi, dan biaya tenaga kerja.

\section{Biaya Bahan Baku}

Biaya bahan baku dalam proses pebuatan kue lumpia meliputi bahan dasar pembuatan kue (kulit dan isian) serta bumbu tambahan yang digunakan. Berikut rincian biaya bahan yang digunakan dalam 1 kali proses produksi dengan menghasilkan 250 pcs kue lumpia siap jual.

Tabel 2 menunjukan bahwa komponen biaya bahan baku pembuatan kue lumpia berupa bahan sayuran (wortel, buncis, kembang kol, tauge, kacang tanah, dun bawang dan daun seledri), bahan kulit lumpia (tepung terigu), bahan pelengkap (telur, sambal instant), bumbu dapur (bawang putih, garam, vetsin, penyedap masakan) dan bahan bakar berupa gas elpiji, dengan rata-rata biaya bahan baku dalam produksi pembuatan kue lumpia adalah sebesar Rp. 143.250 per hari atau dalam satu kali produksi dengan menghasikan sebanyak 250 pcs kue lumpia. Dengan kata lain, untuk memproduksi 1 pcs kue lumpia perlu mengeluarkan biaya bahan baku sebesar Rp. 573.
Tabel 2. Rata-Rata Biaya Bahan Baku Produksi Pembuatan Kue Lumpia

\begin{tabular}{lccc}
\hline $\begin{array}{c}\text { BahanBaku } \\
\text { yang } \\
\text { Digunakan }\end{array}$ & $\begin{array}{c}\text { Pemakaian } \\
\text { bahan }\end{array}$ & $\begin{array}{c}\text { Harga Beli } \\
\text { (Rp/satuan) }\end{array}$ & $\begin{array}{c}\text { Total } \\
\text { Biaya } \\
(\mathbf{R p})\end{array}$ \\
\hline Tepung Terigu & $3 \mathrm{Kg}$ & 8.000 & 24.000 \\
Kembang Kol & $2 \mathrm{Kg}$ & 10.000 & 20.000 \\
Wortel & $2 \mathrm{Kg}$ & 20.000 & 40.000 \\
Tauge & $1 \mathrm{Kg}$ & 5.000 & 5.000 \\
Buncis & $0,5 \mathrm{Kg}$ & 15.000 & 7.500 \\
Kacang Tanah & $0,5 \mathrm{Kg}$ & 30.000 & 15.000 \\
Telur & $5 \mathrm{Butir}$ & 1.800 & 9.000 \\
Garam & 1 Bungkus & 1.000 & 1.000 \\
Vetsin & $1 \mathrm{Bungkus}$ & 1.000 & 1.000 \\
Bawang Putih & $0,25 \mathrm{Kg}$ & 15.000 & 3.750 \\
Daun Bawang & $0,25 \mathrm{Kg}$ & 10.000 & 2.500 \\
Daun Seledri & $0,25 \mathrm{Kg}$ & 12.000 & 3.000 \\
Penyedap & $2 \mathrm{Bungkus}$ & 1.000 & 2.000 \\
Masakan & & & 8.000 \\
Sambal Instant & $1 \mathrm{Botol}$ & 8.000 & 1.500 \\
Gas Elpiji & $0,25 \mathrm{Kg}$ & 6.000 & \\
\hline \multicolumn{1}{c}{ Total Biaya } & & & \\
Bahan Baku & & & \\
\hline Sumber : Data Primer, 2015 & &
\end{tabular}

\section{Biaya Tenaga Kerja}

Penyediaan tenaga kerja merupakan cerminan dari kualitas sumber daya manusia yang ada. Termasuk dalam profesi usaha pembuatan produk kuliner, kualitas tenaga kerja sangat mempengarhi produktifitas kerja. Dalam proses produksi pembuatan kue lumpia, sebagai suatu struktur dasar aktivitas usaha, tenaga kerja yang digunakan merupakan faktor yang sangat penting, karena tenaga kerja tersebut bertindak sebagai pelaku ekonomi yang berbeda dengan faktor produksi lainnya yang bersifat pasif (seperti modal, bahan baku, alat, dan lahan). Hasil penelitian ini menunjukan bahwa dalam industri pembuatan kue lumpia ini, menggunakan 2 orang tenaga kerja, yaitu pemilik usaha itu sendiri dan tenaga bantuan dari luar keluarga, dengan lingkup kerja sejak penyediaan bahan baku, proses produksi, packing hingga distribusi ke tempuat penjualan, dengan upah Rp. 400.000 per 6 hari kerja (senin-jumat), atau sebesar Rp. 66.666 per orang per hari. Maka, setiap harinya 
pemilik usaha mengeluarkan upah tenaga kerja sebesar Rp. 122.222,2 untuk menjalankan usaha kue lumpia tersebut.

\section{Biaya Distribusi}

Dalam memperoleh bahan baku di pasar serta memasarkan hasil produksi ini, tentunya memerlukan alat transportasi agar usaha dapat tetap berjalan dan memenuhi permintaan pasar sesuai waktu yang telah ditentukan. Dalam usaha ini, alat transportas yang digunakan adalah sepeda motor. Setiap harinya pemilik usaha mengeluarkan 2 liter bensin dalam distribusi produk kue lumpia ke golden supermarket dan cella bakery, serta berbelanja bahan baku dipasar. Harga bensin setuiap liternya sebesar Rp. 8.000, maka biaya transportasi yang dikeluarkan adalah sebesar Rp. 16.000

\section{Total Biaya Produksi}

Total biaya produksi kue lumpia meliputi biaya tetap (penyusutan alat dan pajak usaha) dan biaya variabel (meliputi biaya bahan baku, tenaga kerja dan transportasi). Berikut tabel rekapitulasi biaya produksi yang dikeluarkan dalam usaha kue lumpia dalam memproduksi 250 pcs lumpia dalam 1 hari kerja.

\section{Tabel 3. Rekapitulasi Total Biaya Produksi Pembuatan Kue Lumpia}

\begin{tabular}{lc}
\hline \multicolumn{1}{c}{ Jenis Biaya } & Jumlah (Rp) \\
\hline Biaya Penyusutan & 233,3 \\
Alat & $2.191,7$ \\
Pajak Usaha & 143.250 \\
Biaya Bahan Baku & 122.222 \\
Biaya Tenaga Kerja & 16.000 \\
Biaya Transportasi & $\mathbf{2 8 3 . 8 9 6 , 7}$ \\
\hline \multicolumn{1}{c}{ Total Biaya } \\
\hline
\end{tabular}

Sumber : Data Primer, 2015

Tabel 3 menunjukkan bahwa terdapat 5 faktor biaya yang diperhitungkan dalam pelaksanaan usaha kue lumpia ini, yaitu biaya penyusutan alat sebesar Rp. 233,3/hari, biaya pajak usaha sebesar Rp. 2.191,7/hari, biaya pengadaan bahan baku sebesar Rp. 143.250/hari, biaya tenaga kerja sebesar Rp. 122.222/hari dan biaya transportasi untuk distribusi produk sebesar $\mathrm{Rp}$. 16.000/hari. Total biaya produksi yang dikeluarkan dalam 1 hari dengan jumlah unit produksi sebanyak 250 pcs adalah sebesar Rp. 283.896,7/hari. Maka dapat diketahui bahwa untuk memproduksi 1 pcs kue lumpia, produsen mengeluarkan biaya produksi sebesar Rp.1.135,5. Angka ini diperoleh dari pembagian antara total biaya produksi dibagi dengan jumlah pcs kue lumpia yang diproduksi.

\section{Tingkat Produksi, Harga dan Total Penerimaan}

Pada dasarnya, perusahaan dalam meningkatkan produksinya bertujuan untuk meningkatkan keuntungannya. Hasil produksi per hari usaha pembuatan kue lumpia adalah sebanyak 250 pcs kue lumpia. Sedangkan harga jual yang diterapkan adalah sebesar Rp. 4.000 per pcs. Total penerimaan adalah jumlah produksi dikalikan dengan harga jual yang berlaku. Maka dalam usaha ini total penerimaan yang diterima oleh usaha ini dari penjualan kue lumpia adalah sebesar Rp. 1.000.000. Berikut ini adalah perhitungan total penerimaan usaha kue lumpia ini.

Tabel 4. Rekapitulasi Produksi, Harga dan Total Penerimaan Usaha

\begin{tabular}{lc}
\hline \multicolumn{1}{c}{ Jenis Biaya } & Jumlah $($ Rp) \\
\hline Produksi & $250 \mathrm{pcs}$ \\
Harga & Rp. $4.000 / \mathrm{pcs}$ \\
$\begin{array}{l}\text { Total pen- } \\
\text { erimaan }\end{array}$ & Rp. $1.000 .000 /$ hari \\
\hline
\end{tabular}

Sumber : Data Primer, 2015

Tabel 4 menunjukkan bahwa dalam 1 hari kegiatan produksi, Kios Nia mampu menghasilkan produk kue lumpia siap konsumsi sebanyak 250 pcs. Tingkat harga yang ditawarkan kepada pedagang pengecer adalah sebesar Rp. $4.000 /$ pcs. Sehingga dengan rumus penerimaan diperoleh dari perkalian antara jumlah unit produksi (quantity) dikalikan harga, maka total penerimaan yang diperoleh usaha ini dalam 1 kali kegiatan produksi adalah sebesar Rp. 1.000.000/hari. 


\section{Tingkat Keuntungan dan Analisis Revenue Cost of Ratio}

Keuntungan yang diperoleh sangat tergantung dari jumlah penerimaan yang diterima dengan biaya yang dikeluarkan. Semakin besar penerimaan yang diperoleh dan semakin kecil biaya yang dikeluarkan, maka tingkat keuntungan semakin tinggi. Tingkat keuntungan diperoleh dari selisih antara total penerimaan usaha dan total biaya produksi yang dikeluarkan. Berikut ini adalah perhitungan keuntungan usaha ini.

Tabel 5. Total Keuntungan Usaha Kue Lumpia per Hari

\begin{tabular}{lc}
\hline \multicolumn{1}{c}{ Jenis Biaya } & Jumlah $(\mathbf{R p )}$ \\
\hline $\begin{array}{l}\text { Total Pen- } \\
\text { erimaan }\end{array}$ & 1.000 .000 \\
$\begin{array}{l}\text { Total Biaya } \\
\text { Produksi }\end{array}$ & $283.896,7$ \\
\hline $\begin{array}{l}\text { Total Keun- } \\
\text { tungan }\end{array}$ & $\mathbf{7 1 6 . 1 0 3 , 3}$ \\
\hline
\end{tabular}

Sumber : Data Primer, 2015

Tabel 5. menunjukkan bahwa dalam 1 hari kegiatan produksi, Kios Nia mampu menghasilkan total penerimaan (laba kotor) sebesar Rp. 1.000.000. Dimana total produksi adalah 250 pcs dengan tingkat harga sebesar Rp. 4.000/pcs. Sedangkan total biaya produksi untuk 1 kali kegiatan produksi adalah sebesar Rp. 283.896,7. Sehingga dengan rumus keuntungan diperoleh dari pengurangan antara total penerimaan dengan biaya produksi, maka total keuntungan bersih (profit) yang diperoleh usaha ini dalam 1 kali kegiatan produksi adalah sebesar Rp. 716.103,3/hari atau Rp. 2864,4/pcs.

Tingkat keuntungan usaha ekonomi dapat diketahui dengan menggunakan Analisis Revenue of Cost Ratio, yaitu perbandingan antara penerimaan dan keuntungan, dimana jika nilai $\mathrm{R} / \mathrm{C}<$ 1 maka usaha tersebut rugi, jika $\mathrm{R} / \mathrm{C}>1$ maka usaha untung sedangkan jika $\mathrm{R} / \mathrm{C}=1$ maka usaha tersebut tidak untung dan tidak rugi atau impas. Nilai R/C usaha kue lumpia Kios Nia dapat dilihat dalam tabel berikut.
Tabel 6. Analisis R/C Usaha Kue Lumpia Kios Nia

\begin{tabular}{lc}
\hline \multicolumn{1}{c}{ Jenis Biaya } & Jumlah $(\mathbf{R p )}$ \\
\hline Total Penerimaan & 1.000 .000 \\
Total Biaya Produksi & $283.896,7$ \\
\hline \multicolumn{1}{c}{ R/C Ratio } & $\mathbf{3 , 5 2}$ \\
\hline
\end{tabular}

Sumber : Data Primer, 2015

Tabel 6. menunjukan bahwa $\mathrm{R} / \mathrm{C}$ ratio usaha kue lumpia kios Nia adalah sebesar 3,52 yang diperoleh dari pembagian antara Total penerimaan dengan total biaya produksi. Maka dapat diketahui bahwa usaha kue lumpia ini menguntungkan dan layak untuk dijalankan.

\section{KESIMPULAN DAN SARAN}

\section{Kesimpulan}

Hasil penelitian ini menunjukan bahwa :

1. Hasil analisis data menunjukan bahwa rata-rata total penerimaan dalam usaha ini adalah Rp. 1.000.000/hari, dengan total biaya produksi sebesar $\mathrm{Rp}$. 283.896,7. Maka total keuntungan yang diperoleh dalam usaha kue lumpia di Kelurahan Bumi Nyiur Kecamatan Wanea adalah sebesar Rp. 716.103,3/hari.

2. Analisis $\mathrm{R} / \mathrm{C}$ yang dilakukan menunjukan bahwa secara rata-rata usaha rumah tangga pembuatan kue lumpia di Kelurahan Bumi Nyiur Kecamatan Wanea mengalami keuntungan, dimana dengan $\mathrm{R} / \mathrm{C}$ ratio sebesar 3,52 (usaha layak dijalankan)

\section{Saran}

Berkaitan dengan hasil penelitian ini, maka pengembangan usaha ini perlu ditingkatkan dalam jumlah produksinya, khususnya perlu juga dilakukan penambahan volume tenaga kerja dan bahan baku, sehingga meskipun biaya produksi bertambah, tetapi keuntungan usaha dapat meningkat 
lebih dari penambahan biaya produksi yang terjadi, sekaligus dapat menambah kesempatan kerja dalam masyarakat. Serta dilakukan usaha pelebaran usaha pemasaran dan distribusi agar lebih mengena ke lebih besar cakupan pangsa konsumen umum, sehingga penjualan tidak hanya terfokus di 3 pedagang pengecer saja.

\section{DAFTAR PUSTAKA}

Andana. 2010. Kiat Memulai Usaha Kuliner. Bina Aksara. Jakarta

Ardisaputro. 2008. Paradigma Pengolahan Produk Pertanian Berbasis Agribisnis di Riau. Jurnal Ilmiah Universitas Riau Vol.13 Ta hun Kedua. Riau.

Balkaoui. 2005. Teori Produksi Edisi Pertama. Penerbit Salemba Empat. Jakarta

Dantes, 2012. Metode Penelitian. Yogyakarta. Andi Offset. Surabaya

Kotler. 2006. Manajemen Pemasaran Edisi 3. PT. Gramedia Press. Jakarta

Kuriawan. 2005. Pengolahan Pangan Berbasis Teknologi. Kanisius. Yogyakarta

Kwartono, Adi. 2007. Analisis Usaha Kecil Dan Menengah. CV. Andi Offset. Yogyakarta

Lamun. 2008. Berbisnis Kue Lumpia Surabaya. PT. Erlangga. Jakarta

Moehar. 2005. Metode Penelitian Sosial Ekonomi. Bumi Angkasa. Jakarta

Nitisusastro. 2012. Perilaku Konsumen dalam Perspektif Kewirausahaan. Alfabeta. Bandung
Padmowiharjo. 2004. Pengantar Industri Pertanian. UI Press. Jakarta

Primiana. 2009. Menggerakkan Sektor Riil UKM \& Industri. Alfabeta. Bandung

Rusli. 2010. Pergerakan Industri Rumah Tangga dan UMKM di Indonesia. PT. Gramedia. Jakarta

Sugiyono. 2007. Statistika untuk Penelitian. Alfabeta. Bandung

Sumarsono. 2003. Efektifitas Tenaga Kerja dalam Teori Produksi. Gajahmada Press. Yogyakarta

Swasta. 2006. Manajemen Distribusi dan Pemasaran Modern. UI Press. Jakarta

Tambunan, Robert. 2004. Analisa Keuntungan Industri Berbasis Pertanian. Universitas Indonesia Press. Jakarta

Tohar, 2011, Membuka Usaha Kecil. Penerbit Kanisius. Yogyakarta

Wilson. 2007. Teori dan Analisi Biaya. Penerbit Grafindo. Jakarta

Zulkarnain. 2006. Kewirausahaan Strategi Pemberdayaan Usaha Kecil Menengah Dan Penduduk Miskin. Penerbit Adi Cipta Karya Nusa. Yogyakarta 